\title{
Leiomioma uretral
}

\author{
Vallmanya Llena FR, Rijo Mora E, Hernández Pozo H, Del Canto Aguirre M, Lorente Garin JA, \\ Gelabert Mas A.
}

Servicio y Cátedra de Urología. Hospital del Mar. Universitat Autónoma de Barcelona. Barcelona.

\author{
Actas Urol Esp. 2007;31(10):1196
}

$\mathrm{P}$ aciente mujer de 40 años de edad, diagnosticada de útero miomatoso y masa pélvica a raíz de metrorragias. Se realizó histerectomía total abdominal simple por parte del servicio de Ginecología-Obstetricia de nuestro centro, siendo difícil el abordaje quirúrgico de la masa pélvica, por lo que no se realiza exéresis de la misma y se nos remite la paciente para valoración y tratamiento.

La paciente refería clínica de urgencia de meses de evolución y disminución en la fuerza y calibre de su chorro urinario. El examen físico revela una gran masa elástica de $7 \mathrm{~cm}$. que rechaza la pared vaginal anterior, bien delimitada y dificil de abarcar en el plano longitudinal.

Tras valorar la RNM realizada previamente a la histerectomía (Fig. 1), se solicita UIV (Fig. 2), que objetiva residuo postmiccional moderado y uréteres sobreelevados.

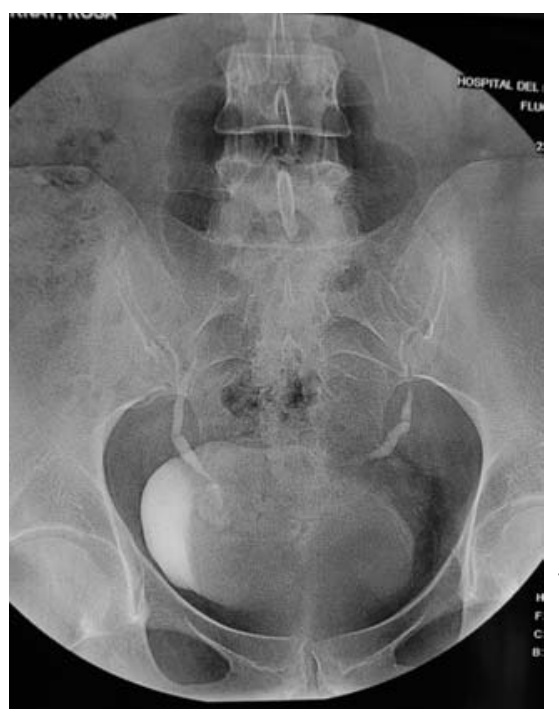

FIGURA 1. UTV; vejiga con marcado defecto de repleción en suelo $y$ uréteres sobreelevados.

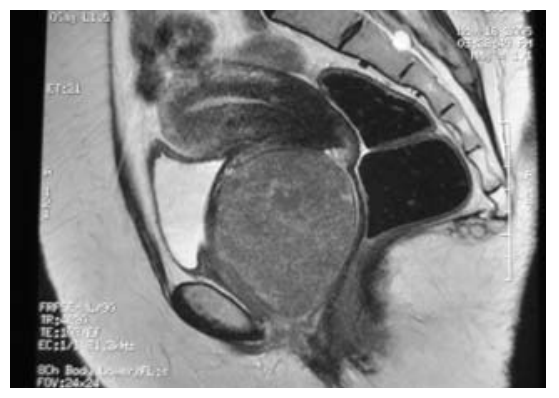

FIGURA 2. RNM potenciado en $T 1$. Masa pélvica en tabique uretro-vaginal, dependiente de uretra, que condiciona desplazamiento de estructuras vecinas.
Con la orientación diagnóstica de leiomioma uretral, se realiza exéresis del mismo con abordaje vaginal (Figs. 3 y 4). La AP confirma el diagnóstico.

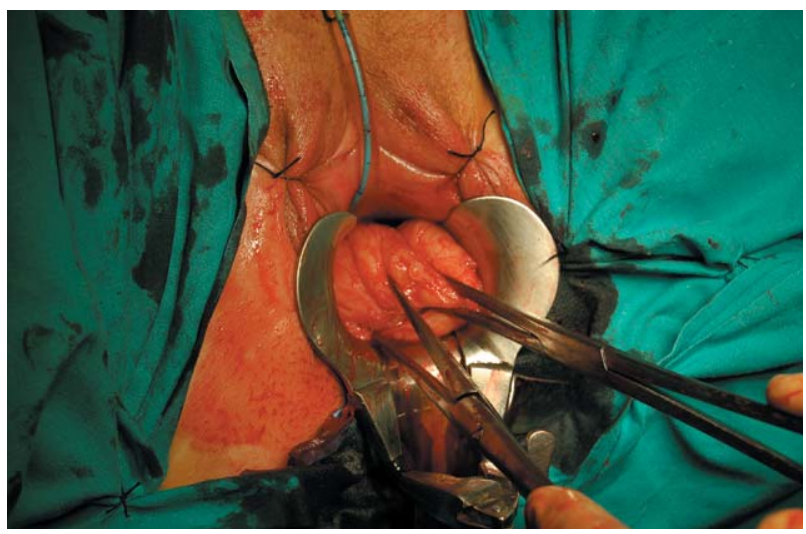

FIGURA 3. Abordaje vaginal.

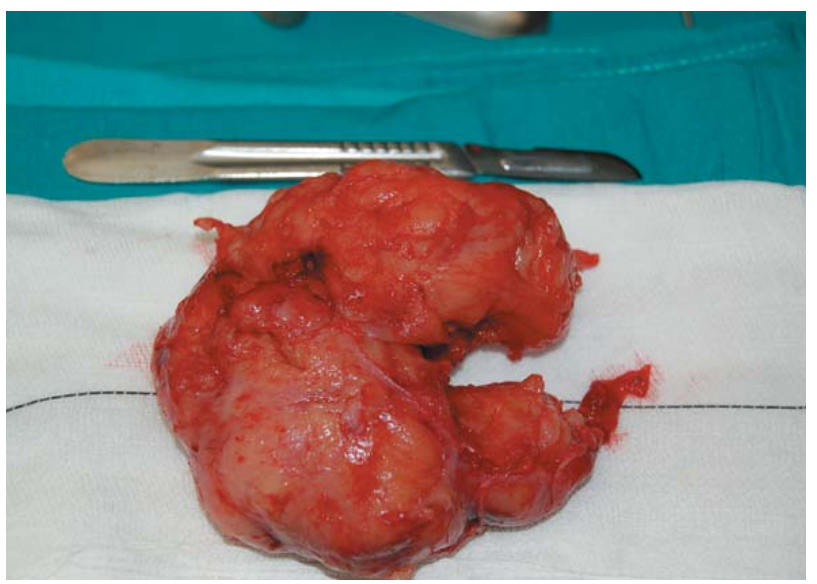

FIGURA 4. Pieza; fragmento de tejido de 113x 100x $23 \mathrm{~mm}$.

Correspondencia autor: Dr. F.R. Vallmanya Llena Servicio y Cátedra de Urología. Hospital del Mar Passeig Maritim, 25-29 - 08003 Barcelona Tel.: 932483000

E-mail autor: fvallmanya@imas.imim.es

Información artículo: Imágenes en Urología

Trabajo recibido: septiembre 2006

Trabajo aceptado: octubre 2006 